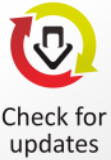

updates

\section{Understanding on and Need for Syaria Insurance: A Case Study in Pekalongan, Central Java, Indonesia}

\author{
Kuat Ismanto*
}

ABSTRACT: Objective of the study was to explore how much Pekalongan residents understand and need Syaria insurance in Indonesia. The data collection methods were questionnaire and interview. The questionnaires were distributed randomly to 136 samples/ respondents. The interview was conducted to 10 informants in order to elaborate meaning, respondent's understanding need and response on syaria insurance. The data analysis method was descriptive-qualitative analysis. The findings showed that most respondents had good level of understanding on syaria insurance. Some respondents stated that insurance was "important" while some others stated that it was "very important." The respondents considered syaria insurance as investment, financial solution, financial security, business requirement, pension plan and future investment. However, the respondents had very basic understanding on syaria insurance. They associated syaria insurance with Islamic-based insurance and non usury (excessive interest). It implied that there is a market for syaria insurance in this city. It is expected that government and companies support development of syaria insurance in Indonesia.

Ismanto, K. (2018). Employees' Understanding on and Need for Syaria Insurance: A Case Study in Pekalongan, Central Java, Indonesia. Journal of Accounting and Investment, 19(2), 137-148.

\section{Received:}

23 January 2018

Reviewed:

12 March 2018

Revised:

05 April 2018

\section{Accepted:}

06 April 2018

\section{Copyright: (C) 2018}

Ismanto. This is an open access article distributed under the terms of the Creative Commons Attribution License, which permits unrestricted use, distribution, and reproduction in any medium, provided the original author and source are credited.
KEYWORDS: syaria insurance; knowledge on insurance; perception on insurance;

\section{Introduction}

Conventional and syaria insurance has different function but different operating system. Some argue that conventional insurance does not represent the teaching of Islam (Hussain \& Pasha, 2011). Syaria insurance is the solution for this problem. Htay and Salman (2013) and Noordin (2014) state that syraia insurance or known as "takaful" is based on kindness (tabarru') and collaborative work (ta'awun). Based on fatwa from National Syaria Council of Indonesian Council of Ulama (Dewan Syari'ah Nasional Majelis Ulama Indonesia /DSN-MUI), No.21/DSN-MUI/X/2001, about Guideline for Syaria Insurance, insurance (ta'min, takaful atau tadhamun) referred an effort to protect or collaborative work between a number of individuals/ institutions through investment and in the form of asset and/or tabarru' in which a formal agreement ( $a k a d$ ) becomes requirement.

Syaria insurance uses various type of formal agreement (akad muamalat) as its operational basis. Examples of syaria insurance in several countries are mudharabah, wakalah, and wakaf (Abdullah \& Yaacob, 2012; Wahab, 2006; Noordin, 2014; Nu, Htay, \& Zaharin, 2012). These models are result of independent reasoning to create an ideal syaria insurance. In another context, criticism towards particular concept was the reason to develop another one. Syaria insurance experts are striving to develop concept for syaria insurance until recently. need for insurance 
Development of Islamic finance is part of phenomenon taking place in the world, more particularly in Moslem-dominant country (Pepinsky, 2013). Islamic Insurance Company, the first insurance, was established in Suand in 1979 (Hosen, 2013; Alnemer, 2013). Malaysia and Indonesia are two countries that develop similar insurance. Islamic-based insurance also spreads to other Asian and European countries. The first syaria insurance company, PT. Syarikat Takaful Indonesia, was established in 1994. This insurance, part of world's syaria financial instrument, is a well-known insurance in Indonesia including Pekalongan.

Despite of growing trend of syaria insurance, conventional insurance is dominant type of insurance in Malaysia (Asmak, Shamsiah, Wan Marhani, Wan Ahmad, \& Mohd Fauzi., 2011). Some factors affect growth of syaria insurance and public acceptance of the insurance. Ayinde and Echchabi (2012) stated that linearity between product and knowledge became deciding factors to choose syria insurance in Malaysia. Coolen-Maturi (2013) mentioned that British had limited information on syaria insurance and therefore, its penetration was relatively low. In Bahrain, understanding towards syaria insurance was high and as the result, it was growing rapidly in the country (Hidayat \& Rafeea, 2014).

The researcher had analyzed insurance based on Islamic perspective (Ismanto, 2009), and maqasid asy-syariah perspective (Ismanto, 2016). The researcher also conducted field observation on the implementation of syaria in syaria insurance akad (Ismanto, 2014). Hosen (2013) stated that experts in contemporary Islamic law allow ta'awuni (social collaborative work) using tabarru' (kindness) akad, but forbid commercial insurance because it contained usury and gharar.

Using normative law of Islam, Mubarrak (2016) responded Indonesian Council of Ulama's fatwa about Indonesian Social Security (Badan Penyelenggara Jaminan Sosial/ BPJS). BPJS is cegorized as insurance but some of its operating system are against syaria law, for example fine ( $2 \%$ from insurance fee) for late payment. BPJS management cannot guarantee if the insurance does not involve any type of gambling (maysir), uncertainty (gharar), and interest (ribâ) that are against the teaching of Islam. Practice of insurance that uses 2001 DSN MUI fatwa number 1 about guideline for syaria insurance is the best solution. The researcher agrees upon Indonesian Councul of Ulama fatwa on BPJS. This fatwa affects Indonesian perception towards insurance.

Rahim (2013)'s study revealed that taking global and national economy into account national economics has significant influence towards development of syaria insurance in Indonesia. Maksum (2011) argued that public responses towards syaria-based financial system is important factor in syaria insurance prospect in Indonesia. Nevertheless, the authority, for example Sharia Supervisory Board (Dewan Pengawas Syariah/DPS) has not paid enough attention on syaria insurance yet.

Fayshal and Medyawati (2013) conducted an analysis on syaria insurance marketing. They argued that the most important aspect of syaria insurance marketing is promotion. Having run literature analysis, Hidayat (2015) found out that education played pivotal role in increasing knowledge of the society 
on syaria insurance concepts and principles. Using SEM analysis and t-test, Ayinde and Echchabi (2012) showed match between product and knowledge is the basis for Malaysian to choose syaria insurance. Using quantitaive analysis and Anova, Jabeur (2015) argued that religious belief (Islam) reduced consumerism and consumer willingness to buy life insurance, either conventional or syaria, in Tunisia. These conclusions may be used for religion-based product or service.

There are 55 syaria-based insurance companies in Indonesia in 2015. 3 of these companies implemented syaria law completely and 25 of them are public institutions who have syaria business unit. 24 companies provide syaria-based life insurance while 3 companies have reinsurance of sharia business unit (OJK, 2018). Even though number of companies that provide syaria insurance is increasing annually, their market share is only $4.62 \%$ compared to conventional insurance (finance.detik.com, 2018).

This study described public perception on syaria insurance. It focused on two aspects, namely meaning and importance of insurance for the public and their need for syaria insurance. These aspects helped researcher investigate development of syaria insurance industry in Indonesia. The main consideration was individual need would influence his or her decision to purchase.

Pekalongan was selected because the city, located on the north coast of Java, is well-known for its trading and one of the Moslem-dominant cities in Indonesia. This city has strong Islamic traditions. Famous Islamic religious leaders live and were buried in Pekalongan. At last, a branch office of syaria insurance company was recently closed in this city.

\section{Literature Review and Research Focus}

\section{Syaria Insurance Definition and History}

Syaria insurance, well-known as takaful, is Islamic-based insurance. Its objective is equality among members (Hussain \& Pasha, 2013). Hence, the bases of syaria insurance are helping and protecting each other. These represent Holy Qur'an and Hadits.

Based on the 2001 DSN-MUI fatwa number 21, syaria insurance (ta'min, takaful atau tadhamun) referred an effort to protect or collaborative work between a number of individuals/ institutions through investment and in the form of asset and/or tabarru' in which a formal agreement ( $a k a d)$ becomes requirement.

The first modern syaria insurance company, Islamic Insurance Co. Ltd., was established in Sudan in 1979 (Hussain \& Pasha, 2011: 24). The first syaria insurance company in Asia was established in Malaysia in 1984 di Malaysia, and in 1994, PT. Syarikat Takaful Indonesia became the first syaria insurance company in Indonesia. Historically, syaria insurance practice can be traced back to practice of aqilah that existed before the Prophet Muhammad SAW. This practice developed in the era of the second khalifa, Umar bin Khatab. 
Table 1 Difference between Syaria and Conventional Insurance

\begin{tabular}{|c|c|c|}
\hline Aspect & Syaria insurance & Conventional Insurance \\
\hline Basis & Al-Qur'an and Hadits & $\begin{array}{l}\text { Law of positivism and developed } \\
\text { based on human ideas }\end{array}$ \\
\hline Concept & Based on mutual help (ta'awun) & Based on agreement \\
\hline Prohibition of Islam & Avoiding riba, maysir, and gharar & May involve riba, maysir, gharar \\
\hline Investment & Halal as boundary & No boundary \\
\hline Syraia Supervisory Board & Dewan Pengawas Syariah (DPS) & None \\
\hline Accounting System & cash basis & accrual basis \\
\hline Premium & Tabarru' and saving account & Interest and fee \\
\hline
\end{tabular}

\section{Difference between Syaria and Conventional Insurance}

Syaria insurance was established due to different opinion between Moslem religious leaders about conventional insurance law. The first group prohibited conventional insurance, the second group allowed social insurance (halal) but prohibited commercial insurance and others stated that the Islamic law on insurance was unclear (syubhat) (Ismanto, 2016). Table 1 described the discrepancy between conventional and syaria insurance.

Syaria insurance has been established for 24 years. However, its market share is only $3.45 \%$ compared to compulsory and social insurance (www.detik.com, 2018). One of the research questions was how much public understands syaria insurance. As a Moslem-dominant country, Syria insurance is growing rapidly in but its market share is low. Ideally, it should have higher market show because it has clear captive market.

The objective of the study was to explain public perception on syaria insurance. Therefore, the research questions:

$R Q_{1}:$ What is definition and importance of insurance for the society?

$R Q_{2}$ : How much does the society need syaria insurance?

\section{Research Method}

\section{Type and Approach}

The study was field research with descriptive-qualitative approach. The data collection method was survey and the instruments were questionnaire and interview. The approach was selected because the aim of the study was to run in-depth analysis on consumer behavior towards a product (Bungin, 2017). Using this approach, the researcher got some insights for hypothesistesting.

\section{Data Sources}

The study had primary and secondary data. Questionnaire and interview were data collection methods to obtain the primary data. The questionnaire was distributed randomly to 136 respondents. The quantitative data described general overview and the respondents' profiles while the 
qualitative data supported the quantitative one. Documentation was the method used for collecting the secondary data. The researcher analyzed the findings of the previous studies and relevant literature.

\section{Informant and Sampling}

The researcher interviewed some of the respondents after they filled out the questionnaires. The interview was conducted in Pekalongan. The sampling method was purposive sampling (Bungin, 2017). The researcher interviewed 10 (ten) out 136 respondents. The criteria were have willingness to participate in the interview, represent each type of occupation and do not have any insurance. The researcher took some notes during the interview.

\section{Data Analysis}

The data analysis method was descriptive-qualitative study. The data analysis involved data reduction, data display and conclusion drawing) (Sugiyono, 2014). The researcher presented the qualitative data and then followed by the result of the interviewed.

\section{List of Question for the Informants}

The researchers formulated two research questions in order to achieve the objectives of the study (see Table 2). These questions are also used as guideline to design question items for the interview.

\section{Result and Discussion}

\section{Respondent's Characteristics}

The total number of respondents were 136. Most of them are male. They had different age range and different kinds of occupation. Table 3 showed the respondents' gender, occupation and age.

\section{Knowledge on Syaria Insurance Aspects}

Syaria insurance is different from conventional insurance. Its operating system is based on akad (formal agreement) called mudharabah, and it prevents maysir, gharar, and riba. In addition, syaria insurance premium from customers is invested in halal financial instrumentation and its practice is supervised by DPS, Syaria Supervisory Board. Table 4 described the respondents' knowledge on syaria insurance aspects.

Based on Table 4, 92 respondents were familiar with the term syaria insurance, while the remaining 44 respondents were not. Most of the respondents (100 respondents) did not know that "takaful" is the synonym of syaria insurance and the remaining 36 respondents did. These two informants were familiar with the term syaria insurance but their knowledge on syaria insurance concepts was lacking. Informant 1 stated that: 
Table 2 List of Questions

\begin{tabular}{|c|c|c|c|}
\hline Objective of the Study & Aspect of The study & Background & Question Items \\
\hline $\begin{array}{l}\text { Explore individual } \\
\text { understanding/ knowledge } \\
\text { on syaria insurance and } \\
\text { aspects of syaria insurance }\end{array}$ & $\begin{array}{l}\text { 1. Syaria insurance } \\
\text { terminology } \\
\text { and concept } \\
\text { 2. Aspects of } \\
\text { syaria insurance }\end{array}$ & $\begin{array}{l}\text { Based on } \\
\text { decision-making } \\
\text { theory, an } \\
\text { individual has } \\
\text { tendency to } \\
\text { purchase a } \\
\text { product when } \\
\text { he or she knows } \\
\text { name and } \\
\text { significant of the } \\
\text { product }\end{array}$ & $\begin{array}{l}\text { a. Are you familiar with the } \\
\text { term syaria insurance and } \\
\text { takaful? } \\
\text { b. How did you get information } \\
\text { about syaria insurance? } \\
\text { c. Do you know difference } \\
\text { between syaria and } \\
\text { conventional insurance? } \\
\text { d. Do you know that syaria } \\
\text { insurance gharar, maysir, } \\
\text { and riba? } \\
\text { e. Do you know that syaria } \\
\text { insurance premium is } \\
\text { invested to halal instrument? } \\
\text { f. Do you know that syaria } \\
\text { insurance operation is } \\
\text { supervised by DPS (Syaria } \\
\text { Supervisory Board)? }\end{array}$ \\
\hline $\begin{array}{l}\text { Describe public need for } \\
\text { syaria insurance }\end{array}$ & $\begin{array}{l}\text { 1. Willingness to } \\
\text { buy syaria } \\
\text { product } \\
\text { insurance } \\
\text { 2. Need for } \\
\text { insurance }\end{array}$ & $\begin{array}{l}\text { Information on } \\
\text { public need for } \\
\text { insurance helps } \\
\text { measuring } \\
\text { degree of } \\
\text { insurance need }\end{array}$ & $\begin{array}{l}\text { a. How did you get information } \\
\text { on syaria insurance and } \\
\text { whether or not such } \\
\text { information is accessible? } \\
\text { b. How important is insurance } \\
\text { for you? } \\
\text { c. Are you sure syaria insurance } \\
\text { has represented the teaching } \\
\text { of Islam? }\end{array}$ \\
\hline
\end{tabular}

Table 3 Respondent's Profile

\begin{tabular}{|l|l|c|}
\hline \multirow{5}{*}{ Gender } & \multicolumn{1}{|c|}{ Category } & Total \\
\hline \multirow{5}{*}{ Occupation } & Male & 50 \\
\hline \multirow{5}{*}{ Female } & 3 \\
\hline \multirow{5}{*}{ Age } & Professional & 7 \\
\hline & University Lecturer & 11 \\
\hline & Teacher & 18 \\
\hline & Staff & 22 \\
\hline & Housewife & 34 \\
\hline & Student & 19 \\
\hline & Entrepreneur & 22 \\
\hline & Other & 64 \\
\hline & Less than 25 years old & 28 \\
\hline & $25-35$ years old & 25 \\
\hline & $36-45$ years old & 13 \\
\hline \multirow{5}{*}{ Total of Respondent } & $46-55$ years old & 6 \\
\hline & 56 or older & 136 \\
\hline
\end{tabular}


Table 4 Respondent's Knowledge on Aspects of Syaria Insurance

\begin{tabular}{|l|c|c|}
\hline \multicolumn{1}{|c|}{ Aspect } & Category & Total \\
\hline Syaria insurance as terminology & Familiar & 92 \\
\hline Takaful as terminology & Not Familiar & 44 \\
\hline Difference between syaria and conventional insurance & Familiar & 36 \\
\hline Akad (formal agreement) mudharabah in syaria insurance & Familiar & 100 \\
\hline Akad (formal agreement) tabarru' in syaria insurance & Not Familiar & 52 \\
\hline Syaria insurance is against maysir, gharar, riba, etc & Familiar & 79 \\
\hline Investment in halal instrumentation & Not Familiar & 57 \\
\hline Supervised by Syaria Supervisory Board (Dewan Pengawas Syariah) & Familiar & 37 \\
\hline
\end{tabular}

"... In my opinion, syaria insurance is the same as the conventional one because syaria insurance companies gain a lot of profit from their customers. Adding the word "syaria" in front of the word "insurance" is not more than marketing strategy. I am not really familiar with syaria insurance because information and promotion on the insurance is limited."

A group of informants associated syaria insurance as "type of insurance who applies the principles of Islam (Allah SWT)." Another group said "syaria insurance is related to the norms of Islam while formal agreement ( $a k a d$ ) for conventional insurance is similar to process of trading." Some others explained that syaria insurance has the same benefit as conventional one, means of protection. However, their operating systems are different.

Based on the questionnaires, 82 respondents were able to distinguish between syaria and conventional insurance while the remaining 54 respondents were not. An informant who works as fisherman mentioned that "syaria insurance is Islamic principles and syaria-based insurance." Informant 2, who worked as a staff in a company, stated that:

".... There is not much different between conventional and syaria insurance. Syaria insurance customers do not get any monthly interest. They are more interested in helping other people."

Another informant, a student, postulated that syaria and conventional insurance were similar. This informant explained that:

"...The only difference between syaria and conventional insurance is their terminology. Syaria insurance focuses on helping other people."

There are two important kinds of akad (formal agreement) in mudharabah (cooperative work) and tabarru' (mutual help). Some examples of syaria insurance were wakalah, wakaf, and also mudaharabah (Ayinde \& Echchabi, 2012; Alnemer, 2013; Echchabi, Olorogun, \& Azouzi, 2014; Echchabi \& Ayedh, 2015). Mudharabah was the most common type of syaria insurance 
in Indonesia. Akad (formal agreement) mudharabah was carried out between syaria insurance customer and company. The customer was considered as Shahibul Maal (owner) and the company as Mudharib (manager and participant). 79 respondents were familiar with mudharabah in syaria insurance but the other 57 respondents were not. Only 37 respondents were familiar with Akad (formal agreement) tabarru' in syaria insurance, while the other 99 respondents were not.

92 respondents understood that syaria insurance prohibited maysir, gharar, and riba, but 44 others did not. The respondents did not have elaborated information about definition of maysir, gharar, and riba, but they understood their basic concepts, for example the respondents mentioned syaria insurance as type of insurance that applies the principles of Islam/ Allah SWT.

Syaria insurance premium was invested in halal financial instrumentation such as syaria stock, syaria mutual funds, syaria-based direct investment, syaria deposit, and syaria financial documents. Based on Table 3, 74 respondents were familiar with tabarru'while the rest 62 others were not.

Syaria insurance practice in Indonesia is supervised by a board called, Dewan Pengawas Syariah (DPS). Other countries also have similar boards. DPS responsibility is to supervise syaria insurance company in order that it sticks to itssyaria compliance (Ismanto, 2016). Based on the quuestionnaire, 84 respondents were familiar with DPS in syaria insurance system but the other 52 respondents were not.

\section{Syaria Insurance Information and Need}

Individual takes several aspects into account prior to purchasing syaria insurance for instance source of and access to information about syaria insurance, customer's perception about the insurance and to what extent the insurance meets the syaria compliance.

Table 5 showed that 63 respondents got information about syaria insurance from family members or friends, 31 respondents got the information from the internet, 20 respondents got the information from mass media, and 16 respondents got information about the insurance from social media such as Facebook and WA. It means word-of-mouth was the most effective method to spread information about syaria insurance. 77 respondents claimed it was difficult to access syaria insurance information while 58 others stated it was not. It was predicted that type of syaria insurance information that was not accessible was one related to product knowledge.

An informant who worked as teacher stated that a friend gave him/her information about syaria insurance.

"...I know a little about syaria insurance. It is Islamic-based insurance. My friend told me that syaria insurance is more reliable because of its benefit, positive value and Islamic foundation." 
Table 5 Information on and Need for Syaria Insurance

\begin{tabular}{|c|c|c|}
\hline Aspect & Category & Total \\
\hline \multirow{5}{*}{ Source of Infomation } & Internet & 31 \\
\hline & Family member/friend & 63 \\
\hline & Mass Media & 20 \\
\hline & TV/Radio & 9 \\
\hline & Sosial Media (Facebook/WA...) & 16 \\
\hline \multirow{2}{*}{ Access to Information } & Easy & 77 \\
\hline & Difficult & 58 \\
\hline \multirow{3}{*}{ Need for Syaria Insurance } & Compulsory & 17 \\
\hline & Invesment & 106 \\
\hline & Luxury & 6 \\
\hline \multirow{3}{*}{$\begin{array}{l}\text { Perception on Syaria } \\
\text { Insurance }\end{array}$} & Protection & 84 \\
\hline & Mutual Help & 22 \\
\hline & Financing Package & 24 \\
\hline \multirow{3}{*}{ Suitability with Syaria } & Certain & 30 \\
\hline & Uncertain & 38 \\
\hline & Doubtful & 67 \\
\hline
\end{tabular}

The respondents had different perceptions on syaria insurance. 84 respondents associated the insurance to protection, 22 with cooperative work and 24 other with financing package. In terms of function, insurance is protection for human being against risk (Mehr \& Cammack, 1981). Related to need for syaria insurance, 106 respondents considered syaria insurance as investment, 16 respondents considered the insurance as compulsory while the remaining 6 respondents considered it as luxury. Ayinde \& Echchabi (2012) stated that compatibility and product awareness were two detrimental factors before individual decided to buy syaria insurance. An office, selected as one of the respondents, associated insurance as future investment.

“...Insurance helps me anticipating risk that may occur at unpredictable time for example health and life insurance."

Another informant, as student, emphasized importance of insurance for education. The respondent had had insurance for education from a private insurance company. He/she considered insurance as an instrument to minimize risk.

"...Insurance is important because we can hardly predict what is happening in the future. It is impossible to get rid of risk. Risk is unpredictable but insurance can help minimizing the risk."

Another informant who works as fisherman was also aware of importance of insurance for education. He/she associated that kind of education to children education in the future, long-term need, investment and saving for education.

"...to reduce risk /anticipate long-term need/future investment, saving for children education in the future."

Informant who worked as a staff explained importance and benefit of insurance. 
"...Insurance is essential because insurance company will cover certain financial burden such as hospital fee. Some insurance also covers damage caused by fire. At last, life insurance helps taking care of family members of the deceased."

"...I will get some benefits from the insurance I purchase. When my children go to school, their insurance will cover their admission fee. It helps ease my financial burden".

Another informant who owns batik (Indonesian traditional cloth) described relationship between insurance and business.

"...Insurance is an obligation for entrepreneurs. It is one of the requirements to get loan from the bank."

Another informant who works as entrepreneur explained importance of and benefit of insurance.

"... I have Indonesian Medical Insurance (BPJS). When my wife gave birth, BPJS covered their hospital fee and other related expenses. When I had an accident leaving some dents on my car, my car insurance covers all of the maintenance fee."

Important aspect in syaria insurance operating system is syariah compliance. 67 respondents were doubtful that syaria insurance companies had met syaria compliance. 38 respondents were doubtful and the remaining 30 respondents were certain that they had met syaria compliance. The respondents who worked as entrepreneur argued that syaria insurance was not different from the conventional one.

\section{Conclusion}

The objective of the study is to describe/explore public opinion on syaria insurance. The findings showed that majority of the respondents are familiar with syaria insurance and aware of the importance of syaria insurance. The respondents associate insurance with investment, financial security, health, education, financial stability and minimizing risk. However, they have not had comprehensive information on insurance yet and as the consequence, they sometimes have negative perception on the insurance.

The implication is that syaria insurance operator (company) should spread information on syaria insurance and have wider promotion. As a Moslemdominant country, Indonesia is a potential market for syaria insurance (Abduh, Kassim, \& Dahari, 2013). Religion may become a variable affecting Moslem consumer's decision to buy syaria insurance (Sedighi, 2015). Besides that, the operator should design various types of syaria insurance product to meet customer's need that once was fulfilled by conventional insurance.

The limitation of the study is the setting. The study was conducted in Pekalongan and as the consequence, the findings may not be able to describe growth of syaria insurance industry in comprehensive manner. As 
an addition, this study focused only on meaning and importance of syaria insurance when there are a lot more aspects that construct syaria insurance industry. Therefore, future researchers should conduct similar study in wider setting or involving other elements of syaria insurance.

\section{References}

Abduh, M., Kassim, S.H., \& Dahari, Z. (2013). Factors Influence Switching Behavior of Islamic Bank Customers in Malaysia. Journal of Islamic Finance, 2(1), 12-19. doi: 10.12816/0001113.

Abdullah, A., \& Yaacob, H. (2012). Legal and Shariah Issues in the Application of Wakalah-waqf Model in Takaful Industry: An Analysis. Procedia - Social and Behavioral Sciences, 65, 1040-1045. doi: 10.1016/j.sbspro.2012.11.239.

Alnemer, H.A. (2013). Revisiting Takaful Insurance : A Survey on Functions and Dominant Models. Afro Eurasian Studies, 2(1\&2), 231-253.

Asmak, A.R, Shamsiah, M., Wan Marhani, Wan Ahmad, \& Mohd Fauzi, H. (2011). Development of the Islamic insurance business in Malaysia. World Academic of Science, Engineering and Technology, 77(1), 1374-1377.

Ayinde, L. O., \& Echchabi, A. (2012). Perception and adoption of Islamic insurance in Malaysia: An empirical study. World Applied Sciences Journal, 20(3), 407-415. doi: 10.5829/idosi.wasj.2012.20.03.1954.

Bungin, B. (2017). Penelitian Kualitatif: Komunikasi, Ekonomi, Kebijakan Publik, dan Ilmu Sosial Lainnya. Jakarta: Kencana Prenada Media Group.

Coolen-Maturi, T. (2013). Islamic Insurance: Demand and Supply in the UK. International Journal of Islamic and Middle Eastern Finance and Management, 6(2), 87-104. doi: 10.1108/17538391311329806.

Echchabi, A., \& Ayedh, A.M. (2015). Factors influencing the yemeni customers' intention to adopt takaful products. Gadjah Mada International Journal of Business. doi: 10.22146/GAMAIJB.6148.

Echchabi, A., Olorogun, L.A., \& Azouzi, D. (2014). Islamic insurance prospects in Tunisia in the wake of the Jasmine revolution A survey from customers' perspective. International Journal of Operations and Production Management, 34(3), 347-363. doi: 10.1108/IJOPM-06-20120222.

Fayshal, A., \& Medyawati, H. (2013). Analisis Strategi Pemasaran Produk Asuransi Jiwa Pada Bumi Putera Syariah Cabang Depok. Asuransi Dan Manajemen Resiko, 1(2), 48-58.

Hidayat, \& Rafeea, A.M. (2014). Public Awareness Towards Takaful Concept and Principles: A Survey in Bahrain. International Journal of Islamic Banking \& Finance, 4(2). doi: 10.12816/0010778.

Hidayat, S.E. (2015). The Role of Education In Awareness Enhancement of Takaful: A Literature Review. International Journal of Pedagogical Innovations, 3(2), 107-112.

Hosen, M.N. (2013). Mendudukkan status hukum asuransi syariah dalam tinjauan fuqaha kontemporer. Jurnal Wacana Hukum Dan Kemanusiaan, 13(2), 219-232.

Htay, S.N.N., \& Salman, S.A. (2013). Viability of Islamic insurance (Takaful) in India: SWOT analysis approach. Review of European Studies, 5(4), 145-154. doi: $10.5539 /$ res.v5n4p145.

Hussain, M., \& Pasha, A.T. (2011). Conceptual and Operational Differences Between General Takaful and Conventional Insurance. Australian Journal of Business and Management Research, 1(8), 23-28.

Ismanto, K. (2009). Asuransi Syariah: Tinjauan Asas-asas Hukum Islam. Yogyakarta: Pustaka Pelajar. 
Ismanto, K. (2014). Penerapan Prinsip-Prinsip Syariah Pada Perjanjian Asuransi Syariah di RO Takaful Keluarga Pekaongan. Jurnal Hukum Islam, 12(1), 103-116.

Ismanto, K. (2016). Asuransi Perspektif Maqasid Asy-Syari'ah. Yogyakarta: Pustaka Pelajar.

Jabeur, F.S.Y. (2015). The impact of Islamic beliefs on consumers' attitudes and purchase intentions of life insurance. International Journal of Bank Marketing, 33(4). doi: 10.1108/MRR-09-2015-0216.

Mehr \& Cammack. (1981). Dasar-dasar Asuransi. Jakarta: Balai Pustaka.

Mubarrak, H. (2016). Kontroversi Asuransi di Indonesia: Telaah Fatwa Majelis Ulama Indonesia (MUI) tentang Badan Penyelenggara Jaminan Sosial (BPJS). TS AQ AF AH: Jurnal Peradaban Islam, 12(1), 105-130. doi: 10.21111/tsaqafah.v12i1.370

Noordin, K. (2014). The Implementation of Tabbaru' and Ta'awun Contracts in the Takaful Models. Islamic Economics, Banking and Finance: Concepts and Critical Issues., 91-112.

Nu, S., Htay, N., \& Zaharin, H. R. (2012). Critical Analysis on the Choice of Takaful (Islamic Insurance) Operating Models in Malaysia. World Journal of Social Sciences, 2, 112-127.

Pepinsky, T. B. (2013). Development, Social Change, and Islamic Finance in Contemporary Indonesia. World Development, 41(1), 157-167. doi: 10.1016/j.worlddev.2012.06.007.

Rahim, H. (2014). Optimisme Pertumbuhan Asuransi Indonesia ; Proyeksi Perkembangan Lima Tahun (2014-2018 ). Jurnal Asuransi dan Manajemen Resiko, 1-21.

Sedighi, M. (2015). Using co-word analysis method in mapping of the structure of scientific fields (case study: The field of informetrics). Iranian Journal of Information Processing Management, 30(2), 373-396. doi: 10.1108/EL-012014-0022. 